\title{
Petrographic study and its implication to the uniaxial strength of weathered volcanic rocks from Tawau, Sabah
}

\author{
Hennie Fitria W. Soehady Erfen* and Baba Musta \\ Geology Programme, Faculty of Science and Natural Resources, Universiti Malaysia Sabah, Jalan UMS, 88400 Kota Kinabalu, Sabah, Malaysia \\ *Corresponding Author: henniefs@ums.edu.my (H.F.W.S Erfen)
}

Article history :

Received 20 March 2014

Revised 1 July 2014

Accepted 7 July 2014

Available online 6 August 2014

GRAPHICAL ABSTRACT

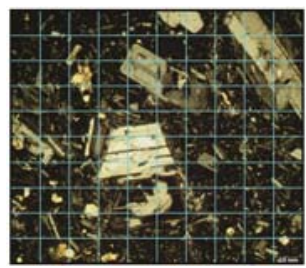

\begin{abstract}
This paper discussed the petrographic study and its effect to the uniaxial strength of weathered volcanic rocks from Tawau, Sabah, Malaysia. The volcanic rock consists of associated dacite, andesite and basalt rocks with the age of Pliocene to Quaternary. In this study the Murphy (1985) classification were used to determine the weathering grade of volcanic rocks. The uniaxial strength value were obtained from the Point Load Test and also estimated calculation from Uniaxial Compressive Strength test. The microstructures and identification of altered minerals were analysed using scanning electron microscope (SEM) and polarized microscope, respectively. The result of analysis indicated that the uniaxial strength of volcanic rocks decreased with the degree of weathering grades where the uniaxial strength decreased from 122.2 to $15.8 \mathrm{MPa}$ for dacite, 143.4 to $10.1 \mathrm{MPa}$ for basalt and 181.2 to 26.8 MPa for andesite. This result is due to the different percentages of quartz and feldspar minerals in the rock samples as well as formation of secondary minerals in weathered rocks. Microstructures study showed the appearance of micro fractures with narrow apertures in the minerals also influenced the uniaxial strength of the rocks.
\end{abstract}

Keywords: Micro fractures, Petrographic study, Uniaxial strength, Volcanic rocks, Weathering

(C) 2014 Penerbit UTM Press. All rights reserved http://dx.doi.org/10.11113/mjfas.v10n3.60

\section{INTRODUCTION}

The strength of rocks varies depending on the rock type, discontinuities and weathering. The effect of weathering on the engineering properties of rocks has been studied by previous researchers and various weathering classification have been proposed [1, 2, 3]. Weathering process consists of chemical, physical and biological dynamic process with agents such as water, air, organism and climate [4]. Chemical weathering is defined as a decomposed process of rocks caused by reactions to water, carbon dioxide and humidity of mineralogy composition [4]. Whereas, physical weathering is a slaking and disintegration process caused by force of water movements, temperature and inner stress changes [5]. Continuous weathering process that occurred has contributed to the decrease of rock physical characteristics [2]. High humidity resulted to extensive chemical weathering process and decrease the physical behaviour [6]. Earth materials can be categorized into five layers according to the weathering grade which does not only limit to the rock surface.

Weathering grade can be classified from Grade II (slightly weathered) to Grade V (completely weathered) based on certain parameters such as color changes, strength index, rocks-soils ratio (RSR) and micro-index (micropetrography, $\mathrm{I}_{\mathrm{mp}}$, and micro-fractures, $\mathrm{I}_{\mathrm{fr}}$, index) [7]. In tropical area the weathering profile can be observed from completely weathered on the surface to fresh rocks at the bottom of the profile. According to Fookes [8], Grade I and II classified as fresh rocks, Grade III and IV as combination of rock and soil, whereas Grade V and VI as soil. However, Irfan and Dearman [3] modified Fookes's classification and can be used for all types of rocks. Weathering processes effects to the strength of rocks due to the formation of soil material and increasing of porosity [6]. The decreasing of strength occurred when the bond between minerals particles is break apart thus forming micro cracks and new minerals during weathering [5]. Therefore, the objective of this research is to study the petrographic and its implication to the uniaxial strength of weathered volcanic rocks, collected from Tawau, Sabah.

The study area is located at Tawau, Sabah which one of the area in east of Sabah has experienced with active volcanic activity. The age of volcanic rocks at the study area is estimated from Pliocene to Quaternary [9]. The Pliocene volcanic rocks are situated at Mt. Magdalena, Mt. Wullersdorf, Mt. Pock, and Mt Lucia while Quaternary volcanic rocks can be found at Mt. Maria, Bombalai Hill, Tiger Hill and Mostyn Hill (Figure 1). The rock 
distributions situated around Tawau town from ApasBalung in the eastern part and Brantian in the western part of Tawau district.

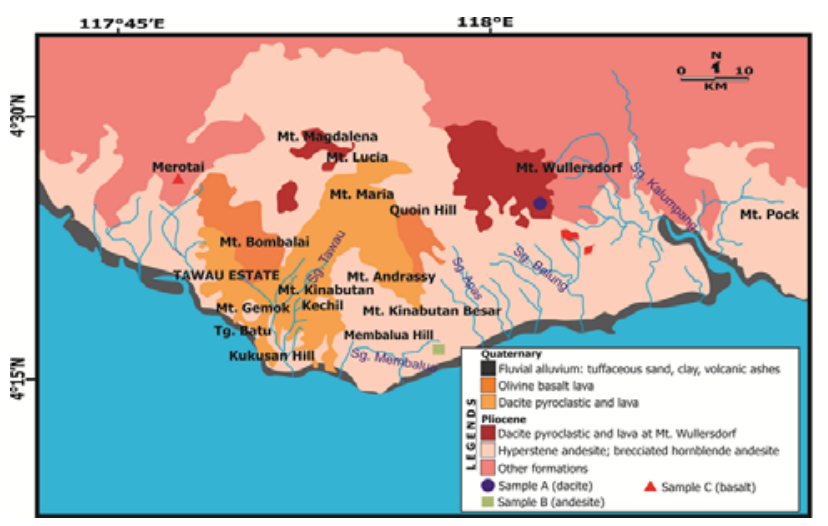

Fig. 1 Geological map of Balung to Merotai, Sabah (modified from Kirk (1962)).

\section{MATERIALS AND METHODS}

Three types of volcanic rocks consist of dacite, andesite and basalt were collected from the study area, which are widely distributed around Balung and Merotai area of Tawau, Sabah (Figure 1). The active weathering process resulted to thick soil profile up to 5 meters in most of the volcanic profiles. The colour is controlled by mineral composition which alter the primary minerals to secondary minerals throughout the weathering Grade II (slightly weathered) to $\mathrm{V}$ (completely weathered).

Petrography plays an important role as volcanic rocks exhibited various mineral composition and texture. Thus, it is crucial to observe how weathering can affect on uniaxial strength of different petrography of volcanic rocks. The classification of rocks samples were done based on QAP diagram to which used to classify volcanic rocks [10].

In this study, weathering grade classification by Murphy [11] (Table 1) is used. Murphy's classification was modified to include the sound and feel of the square end of a rock hammer hitting the rock, though it depends on many external factors including the strength of the person wielding the hammer and the weight of the hammer itself [2]. In-situ sampling was conducted where volcanic rock samples with Grade II to IV of cubic size $(20 \mathrm{~cm}$ x $20 \mathrm{~cm} \mathrm{x}$ $15 \mathrm{~cm}$ ) were collected, except for Grade V where sampling was difficult to be done due to its very weak materials. Grade I was unable to be collected due to its depth and condition for sampling. All samples were then inserted into sample bag and labelled before proceed for laboratory analysis.

Weathering degree also been able to identify with the condition of joints on the surface of rocks. Grade II showedclosed joints with minor color changes; while the opening will increase and filled with calcite and kaolinite in Grade III. At this point half of the volcanic rocks samples had degraded to a residual soil. In highly weathered volcanic rocks (Grade IV), the joint opening increased and the spacing decreased with clay was the common filling. Whereas, Grade V showed nearly $90 \%$ of the material turned to residual soil with clay as main mineral due to hydrolysis of abundance of feldspars in volcanic rocks.

Table 1 Weathering grade classification by Murphy [11]

\begin{tabular}{|l|l|}
\hline Weathering Grade & \multicolumn{1}{|c|}{ Description } \\
\hline Fresh (I) & $\begin{array}{l}\text { No visible signs of weathering. Rock is fresh. Crystals } \\
\text { are bright. The rock hammer rings and bounces back. }\end{array}$ \\
\hline $\begin{array}{l}\text { Slightly Weathered } \\
\text { (II) }\end{array}$ & $\begin{array}{l}\text { Discontinuities are stained or discolored and may contain } \\
\text { a thin filling of altered material. } \\
\text { Discoloration may extend into the rock from the } \\
\text { discontinuity to a distance of 20\% of the discontinuity } \\
\text { spacing. The rock hammer rings and bounces back. }\end{array}$ \\
\hline Moderately & $\begin{array}{l}\text { Slight discoloration extends from discontinuity planes } \\
\text { for a distance of more than 20\% of the discontinuity } \\
\text { spacing. Discontinuities may contain filling of altered } \\
\text { material. Partial opening of grain boundaries observed. } \\
\text { The hammer 'thuds'. }\end{array}$ \\
\hline $\begin{array}{l}\text { Highly Weathed (III) } \\
\text { (IV) }\end{array}$ & $\begin{array}{l}\text { Discoloration extends throughout the rock, and the rock } \\
\text { material is partly friable. The original texture of the } \\
\text { rock has mainly been preserved, but separation of the } \\
\text { grains has occurred. The hammer 'thuds' and fragments } \\
\text { of rock and individual mineral grains on the surface can } \\
\text { easily be broken or rubbed off by hand. }\end{array}$ \\
\hline $\begin{array}{l}\text { Completely } \\
\text { Weathered (V) }\end{array}$ & $\begin{array}{l}\text { The rock is totally discolored and discomposed and in } \\
\text { friable condition. The external appearance is that of a } \\
\text { soil. Internally, the rock texture is partly preserved, but } \\
\text { the grains have been completely separated. The pick } \\
\text { end of the hammer easily enters the rock. }\end{array}$ \\
\hline Residual Soil (VI) & Not included. \\
\hline
\end{tabular}

Uniaxial compressive strength analysis involved of Point Load Test (PLT) and Unconfined Compression Test (UCT) [12] for intact rocks samples. The PLT is an accepted rock mechanics testing method used for the calculation of an intact rock strength index. Also, PLT is a versatile filed based index method capable of deriving values. The data obtained can be used to correlate the PLT index ( $\left.\mathrm{Is}_{50}\right)$ with the uniaxial compressive strength (UCS) [13] and to propose appropriate Is $_{50}$ to UCS conversion factors [12] (Table 2) for volcanic rocks samples. The changes of microstructures in volcanic rocks throughout the weathering process were observed using polarized light microscope model Carl Zeiss and the scanning electron microscope (SEM) technique model Philips XL40 with 60 psi pressure and 15 to $20 \mathrm{kV}$ voltages. The observation of mineral is include of alteration of composition mineral, the existence of micro-fractures and the increment of pore spaces. Mineral percentage is counted using gridding technique of $10 \mathrm{~mm}$ x $10 \mathrm{~mm}$ (Figure 2).

Table 2 Classification of rock strength [12]

\begin{tabular}{|c|c|c|}
\hline Classification & \multirow{2}{*}{ Is $_{\mathbf{5 0}}$ (MPa) } & $\begin{array}{c}\text { Equivalent UCS } \\
(\mathbf{M P a})\end{array}$ \\
\hline Extremely Weak & \multirow{2}{*}{$\begin{array}{c}\text { Generally do not } \\
\text { applies }\end{array}$} & $<0.5$ \\
\cline { 1 - 1 } Very Weak & & $0.5-1.25$ \\
\hline Weak & $0.2-0.5$ & $1.25-5.0$ \\
\hline Moderately Weak & $0.5-2.0$ & $5.0-12.5$ \\
\hline Moderately Strong & $2.0-4.0$ & $12.5-50$ \\
\hline Strong & $4.0-8.0$ & $50-100$ \\
\hline Very Strong & $>8.0$ & $100-200$ \\
\hline Extremely Strong & & $>200$ \\
\hline
\end{tabular}




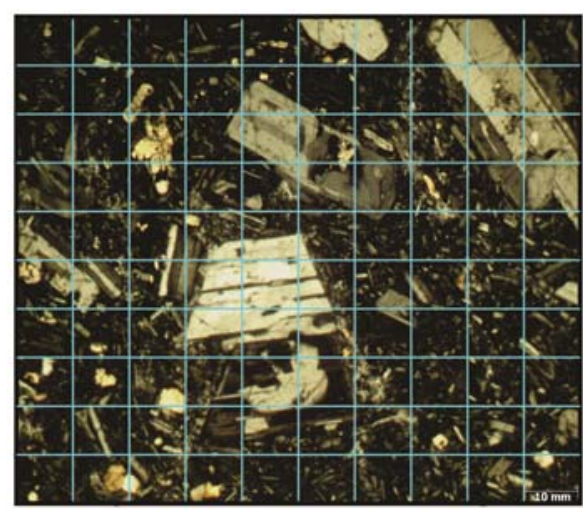

Fig. 2 Gridding technique to count the percentage of minerals exist in rock samples (unscaled).

\section{RESULTS AND DISCUSSION}

\subsection{Volcanic Rocks Classification}

Volcanic rocks samples in the study area were collected based on hand specimen observation and previous references which showed the distribution of volcanic rocks types. To prove the first assumption and interpretation of the type of volcanic rocks collected, further analysis has been done by using QAP diagram [10] to classify the volcanic rocks samples. The percentage of quartz, alkalifeldspar and plagioclase feldspar was counted (Table 3) using gridding technique. The percentages of minerals were then plotted into the triangular chart for the classification of rocks samples. Based on Figure 3, it is found that the volcanic rocks were classified as dacite (Sample A), andesite (Sample B) and basalt (Sample C).

Dacite consists mostly $45 \%$ of plagioclase feldspar with minor appearance of biotite and pyroxene along with rounded quartz (40\%) and phenocrysts. Dacite is intermediate in composition between andesite and rhyolite which the groundmass is composed of plagioclase and quartz (Figure 4A). The petrography features of andesite showed $70 \%$ of plagioclase phenocrysts, $22 \%$ of orthoclase with small amount of quartz (8\%), pyroxene and amphibole in porphyritic texture (Figure 4B). Meanwhile, the petrography features of basalt showed the domination of plagioclase (90\%) and presence of orthoclase (9\%) with minor amount of clinopyroxene and olivine in aphanite texture (Figure 4C).

Table 3 Rock classification based on major mineral composition of volcanic rock samples

\begin{tabular}{|l|c|c|c|}
\hline & Sample A & Sample B & Sample C \\
\hline Quartz, Q (\%) & 40 & 8 & 1 \\
\hline Feldspar, F (\%) & 15 & 22 & 7 \\
\hline Plagioclase, P (\%) & 45 & 70 & 92 \\
\hline $\begin{array}{l}\text { Rock Classification } \\
\text { (Streckeisen, 1978) }\end{array}$ & Dacite & Andesite & Basalt \\
\hline
\end{tabular}

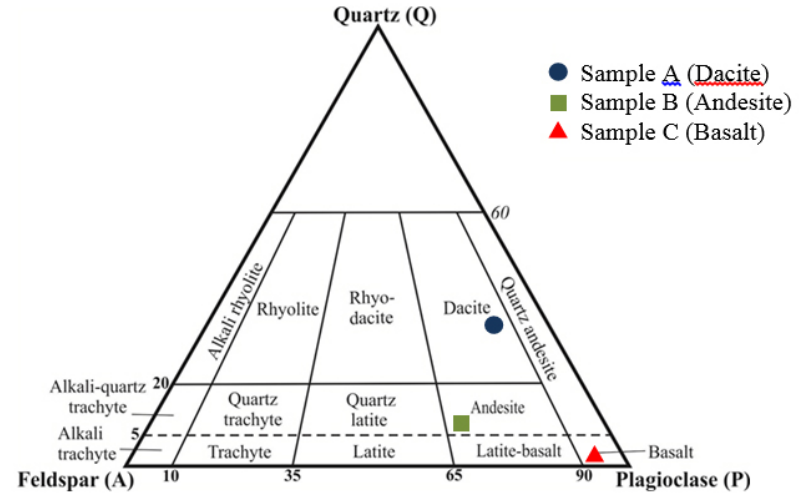

Fig. 3 QAP diagram for volcanic rocks classification
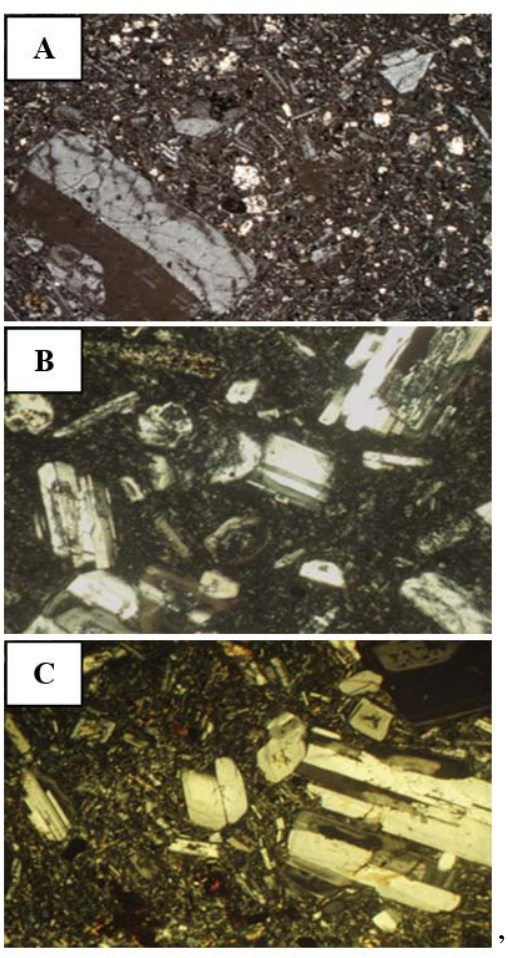

Fig. 4 Photomicrographs show (A) dacite with groundmass is composed of plagioclase and quartz; (B) andesite with plagioclase phenocrysts in porphyritic texture; and (C) and basalt with domination of plagioclase in glassy matrix (20X, XPL).

\subsection{Uniaxial Compression Strength}

Table 4 summarizes the result of uniaxial compression strength test on dacite, andesite and basalt. The result of uniaxial strength of rocks showed that the strength is decreased with the increment of both weathering grade (Table 4). The existence of pores in the inter granular of minerals and micro fractures reduced the strength of rock $[14,15,16]$. However the reduction of uniaxial strength is non-linear with the increment of weathering grade (Figure 5). Failure in the form of fractures resulted in uneven fracture planes in the rock samples.

Based on Figure 5, the relation shown by graphs clearly exhibited higher strength of andesite compare to 
dacite and basalt. Andesite showed higher strength with 181.2 MPa in Grade II; due to the existence of plagioclase phenocrysts and interlocking quartz. This has contributed to high frictional angle which able to cause firmer collision thus increased the strength of particles in andesite [17]. While basalt, gained its 143.4 MPa because of aphanitic texture where fine-grained were tightly packed and dacite with 122.2 MPa due to the dominance of quartz and glassy matrix in this grade. In Grade III, the increment of intra granular micro fractures has decreased the strength of andesite to 104.6 MPa. This, however, still classified andesite as very strong rock [12] due to its porphyritic texture where angular quartz in fine-grained matrix gave higher bonded degree to andesite (Figure 6). Basalt and dacite, meanwhile, showed significant drop of strength to 87.4 MPa and 73.4 MPa respectively, due to the formation of porosity (Figure 7) which caused particles to apart and easy failure.

Table 4. Effect of weathering grade uniaxial strength of volcanic rocks samples

\begin{tabular}{|c|c|c|c|c|c|c|}
\hline \multirow{2}{*}{ Grade } & \multicolumn{2}{|c|}{ Dacite } & \multicolumn{2}{c|}{ Andesite } & \multicolumn{2}{c|}{ Basalt } \\
\cline { 2 - 7 } & MPa & Class & MPa & Class & MPa & Class \\
\hline II & 122.2 & Very Strong & 181.2 & Very Strong & 143.4 & Very Strong \\
\hline III & 73.4 & Strong & 104.6 & Very Strong & 87.4 & Strong \\
\hline IV & 39.4 & $\begin{array}{c}\text { Moderately } \\
\text { Strong }\end{array}$ & 87.7 & Strong & 35.0 & $\begin{array}{c}\text { Moderately } \\
\text { Strong }\end{array}$ \\
\hline V & 15.8 & $\begin{array}{c}\text { Moderately } \\
\text { Weak }\end{array}$ & 26.8 & $\begin{array}{c}\text { Moderately } \\
\text { Strong }\end{array}$ & 10.1 & $\begin{array}{c}\text { Moderately } \\
\text { Weak }\end{array}$ \\
\hline * II-slightly weathered, III-moderately weathered, IV-highly weathered, & & \\
\end{tabular}

V-completely weathered, MPa-strength unit, class-classification of strength

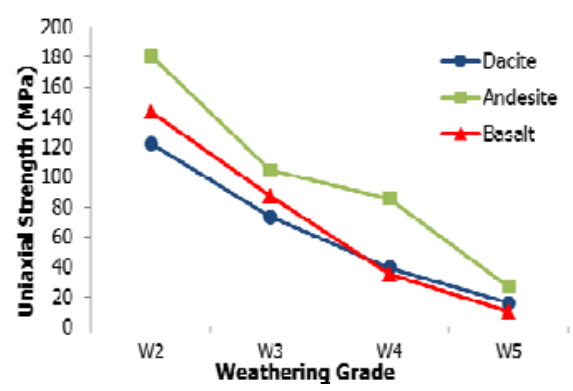

Fig. 5 Relation between uniaxial strength and weathering grade of volcanic rocks which weathering process is able to decrease the strength.

In Grade IV, the uniaxial strength of andesite continue to decrease to $87.7 \mathrm{MPa}$ but still classified as strong, while dacite and basalt showed moderately strong value with 39.4 MPa and 35.0 MPa respectively. This is due to the existence of clay minerals (57.9 \% to 60.2\%) originated from the weathering of feldspars which yielded to increased porosity. Clay minerals reduced the friction angle to $4^{\circ}[17,18]$ which able to affect the initial frictional angle. The formations of micro-fractures caused particles to slide along the failure axis thus decreased the uniaxial strength for volcanic rocks samples in Grade IV.
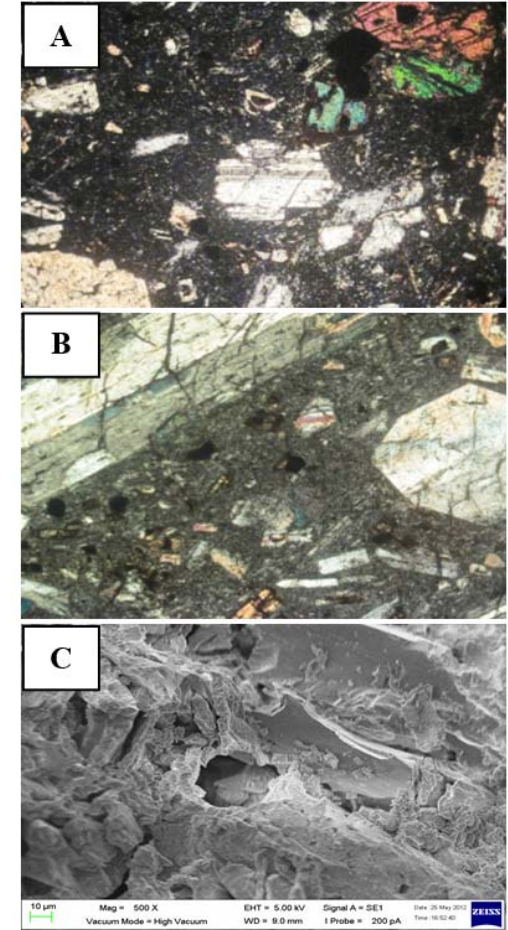

Fig. 6 Andesite showed the existence of (A) interlocking quartz which contributed to high frictional angle. Continuous weathering produces (B) abundance of micro-fractures and (C) porosity which caused particles to slide along the failure axis.
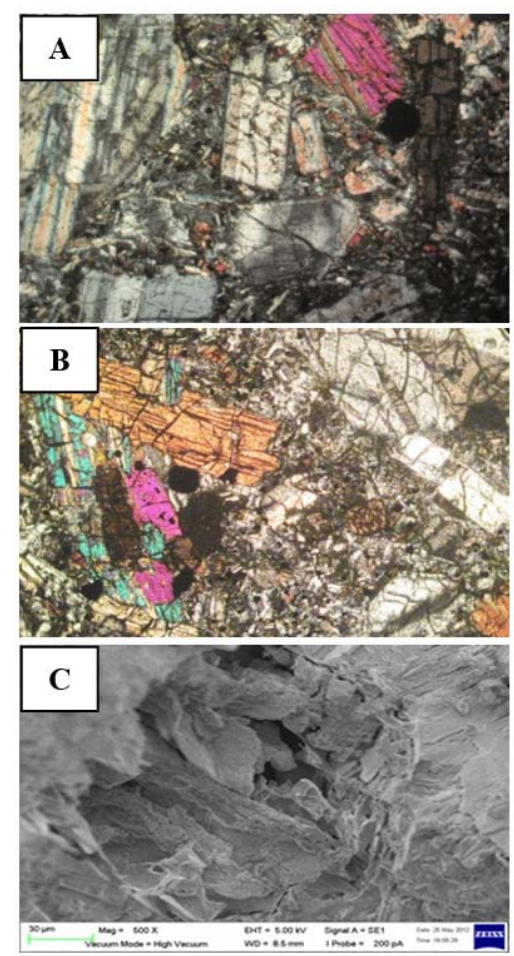

Fig. 7 Dominance of (A) quartz and glassy matrix gave high strength on dacite before decreased due to the (B) increment of intragranular micro-fractures and (C) inter-pores in higher weathering grade. 
All volcanic rocks showed the least uniaxial strength with 26.8 MPa, 15.8 MPa and 10.1 MPa for andesite, dacite and basalt respectively. Both basalt and dacite showed similar strength classification of moderately weak while andesite showed moderately strong value in Grade V. This is due to the homogeneous texture and finegrained with more than 65\% clay domination (Figure 8). Rounded grains initiated easy collision among them thus resulted in low internal friction angle. Basalt showed a higher strength than andesite due to the existence of kaolinite and montmorillonite which played a role as a cohesive material between grains.

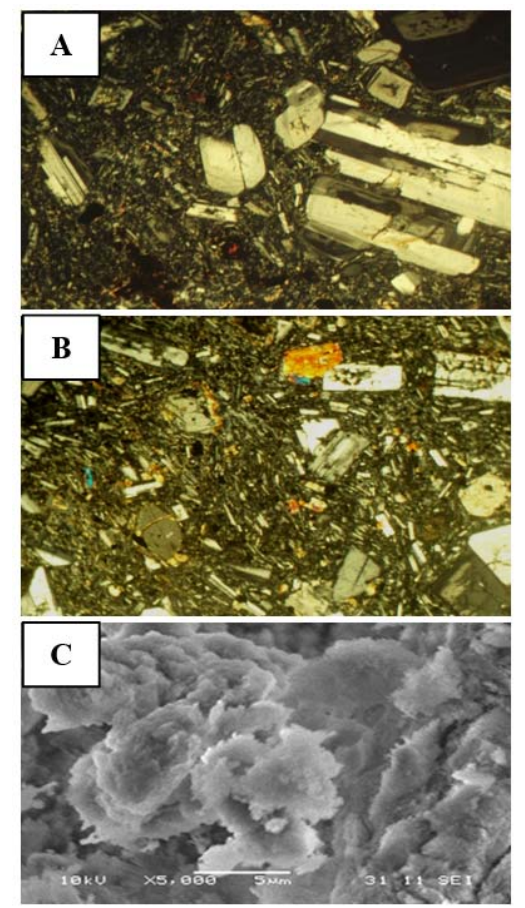

Fig. 8 Decrease in strength due to the existence of clay minerals which reduced the friction angle and produced porosity in basalt.

Slightly weathered rock (Grade II) showed discoloration and $50-60 \%$ of fresh rock strength. $50 \%$ of rock structure will start to disintegrated to possess approximately $30 \%$ of fresh rock strength in moderately weathered grade. It will disintegrate greater up to more than $50 \%$ of structure with less than $15 \%$ of fresh rock strength in highly weathered grade [3]. Under the influence of weathering, the strength, density and volumetric stability of the rock will be reduced, whilst deformability, porosity and weatherability is increased. This can lead to significant reduction in rock strength [19].

\section{CONCLUSION}

Chemical weathering has altered the rock forming minerals in andesite, dacite and basalt volcanic rocks. The weathered rocks formed secondary minerals and pore spaces between mineral grains. The presence of pore spaces, micro fractures and secondary minerals due to the weathering processes affected the uniaxial compressive strength of rocks. Andesite rock with Grade II to IV showed the decrease of strength from 181.2 to $26.8 \mathrm{MPa}$; basalt decreased in strength from 143.4 to $10.1 \mathrm{MPa}$; whereas dacite strength decreased from 122.2 to $15.8 \mathrm{MPa}$.

The primary minerals in volcanic rocks such as quartz and plagioclase which is resistant to the weathering exhibited higher strength or the rocks. However, in weathered volcanic rock the appearance of clay minerals from plagioclase minerals will reduce the strong of the samples. As a conclusion, the weathering process is able to alter the rock forming minerals and micro fabrics of rocks thus reduced the uniaxial strength of the volcanic rocks.

\section{ACKNOWLEDGEMENT}

This study was funded by the UMS research grant No. B-0202-01-PR/U028. Special thanks to Mr. Zulkifly Abdul Wahid from Department of Geotechnical and Transportation, Faculty of Civil Engineering, UTM and Mr. Emran Raga for sample collection and preparation for this study.

\section{REFERENCES}

[1] W. R. Dearman, Bulletin of International Association Engineering Geology 9 (1974) 33.

[2] J. Ehlen, Catena 49 (2002) 91.

[3] T.Y. Irfan,W.R. Dearman, Bulletin of International Association Engineering Geology 17 (1978) 79.

[4] H. D. Tjia, Geomorfologi. Kuala Lumpur: Dewan Bahasa dan Pustaka, 1987.

[5] F.C. Beavis, in: Geologi Kejuruteraan. Ibrahim Komoo \& Tajul Anuar Jamaluddin (Eds.), Dewan Bahasa dan Pustaka. Kuala Lumpur, 1985.

[6] Ibrahim Komoo, Syarahan Perdana Geologi Kejuruteraan Perspektif Rantau Tropika Lembap. Universiti Kebangsaan Malaysia, 1995.

[7] E.W. Brand. Proceedings of 2nd International Conference on Geomechanics in Tropical Soils, 1990, p.515

[8] P.G. Fookes, W.R. Dearclan, I.A Franklin, Quaterly Journal of Engineering Geology. 4 (1971) 139.

[9] H.J.C. Kirk, The Geology and Mineral Resources of Semporna Peninsula North Borneo. Geol. Survey Dept., British Territories in Borneo 14. Sarawak: Government Printing Office, 1962.

[10] A. Streckeisen, Neus Jarhbuch fur Mineralogie Abhandlungen 134 (1978) 1.

[11] W.L. Murphy, Geotechnical Descriptions of Rock and Rock Masses. US Army Engineer Waterway Experiment Station MS GL85, 1985.

[12] International Society of Rock Mechanics. International Journal of Rock Mechanic, Mining Science and Geomechanics. 22 (1985) 51.

[13] E. Broch, J.A. Franklin, International Journal Rock Mechanic Min. Sci. 9 (1972) 669.

[14] C. Chang, M.D. Zoback, A. Khaksar, Journal of Petroleum Science and Engineering. 51 (3-4) (2006) 223

[15] H.F.W. Soehady E., B. Musta. Proc. of the $3^{\text {rd }}$ International Conf. on Southeast Asian Natural Resources and Environmental Management (SANREM), 2010, p.467.

[16] N. Hudyma, B.B. Avar, M. Karakouzian, Engineering Geology 73 (2004) 179.

[17] K. Sassa,H. Fukuoka, F. Wang, G. Wang, Progress in Landslide Science. Berlin: Springer-Verlag. (2007) p. 143

[18] N.A. Al-Shayea, Engineering Geology 62 (4) (2001) 319.

[19] A. Kassim, E.T. Mohammad,. Laboratory Study of Weathered Rock for Surface Excavation Works, 2007. 